\title{
MYCOFLORA ASSOCIATED WITH BASELLA SPP. AND THEIR PATHOGENIC POTENTIALITY
}

\author{
Sufia Akter and Shamim Shamsi* \\ Department of Botany, University of Dhaka, Dhaka-1000, Bangladesh
}

Key words: Mycoflora, Basella spp., pathogenic potentiality

Occurrence of fungi associated with two species of Basella and their pathogenic potentiality is reported. A total of 12 species of fungi representing 8 genera of the class deuteromycetes were found to be associated with Basella alba L. and B. rubra L.. The genus Basella belongs to the Basellaceae family and has two chief cultivars, Basella alba, which bears thick, fleshy, broad, oval to heart-shaped leaves all along its vine length and Basella rubra features pink or purplish stems and pink colour veins in the leaves. In either case, leaves and terminal, tender, 8 - 12 inches stems are ready for harvesting about 35 to 45 days after seeding. Most authors agree, however, that the two color forms of Basella are not separate species. Perhaps both would best be treated as forms of Basella rubra. Basella is native to tropical Asia, probably originating in India or Indonesia. Today, it is grown widely in the tropics. Vine spinach is noted by regional names in different regions in Asia. Some of the common names for this herb are Ceylon spinach, Malabar spinach, saan choy (Chinese), mong toi (Vietnamese), alugbati (Philippines), pui saag (Bengali). remayong (Malay), Indian spinach (English), Poi, Safed bachla (Hindi), etc. Young Basella leaves and stems is popular vegetables in Asian countries. Basella alba is popular for its ethanobotanical properties. Various parts of the plant are used for treatment of the diseases as well as for different healing activities of human beings as well as animals across the globe specially in India and China. Some of the compounds available especially in the plant are basellasaponins, kaempherol, betalin, etc. Several extracts like aqueous, chloroform, ethanol and petroleum has been used for different pharmaceutical activities. Basella is lower in protein than some other leafy vegetables like amaranths, but it is an excellent source of vitamins $\mathrm{A}$ and $\mathrm{C}$ and a good source of calcium and iron (Adhikari et al. 2012). Disease is a constrain for production of the vegetable. Lot of research has been done on its disease and control in abroad but little work has been done on Basella in Bangladesh (Hossain 2007). Present study is undertaken (i) to find the fungi associated with different varieties of Basella and (ii) to study the pathogenic potentiality of the isolated fungi.

Healthy and infected leaves samples of Basella alba and B. rubra were collected from Botanical Garden in the campus of Dhaka University during May, 2012 to June, 2013. Fungi associated with the specimens were isolated following tissue planting methods using potato dextrose agar medium (PDA) (Tuite 1969).

*Corresponding author: <prof.shamsi@gmail.com>. 
The specimens were cut into small pieces $(2 \mathrm{~mm} \times 2 \mathrm{~mm}$ ) and surface sterilized by dipping in $10 \%$ chlorox for 3 - 5 minutes followed by rinsing in sterilized water. From each sample 30 inocula consisted of leaf pieces were taken and placed on solidified PDA in Petri dishes at three pieces per plate. The plates were incubated for 5 - 7 days at $25 \pm 1^{\circ} \mathrm{C}$. Fungi grew from the inocula were transferred to separate PDA plates and PDA slants for further studies and preservation. The isolated fungi were identified based on morphological characteristics observed under a compound microscope following standard keys (Barnett and Hunter 1972, Booth 1971, Ellis 1971, 1976, Ellis and Ellis 1997 and Sutton 1980). Prevalence (\%) of fungi in different specimens was also recorded. All the specimens included in the present study were preserved in the Herbarium, Mycology and Plant pathology section, Department of Botany, University of Dhaka, Bangladesh.

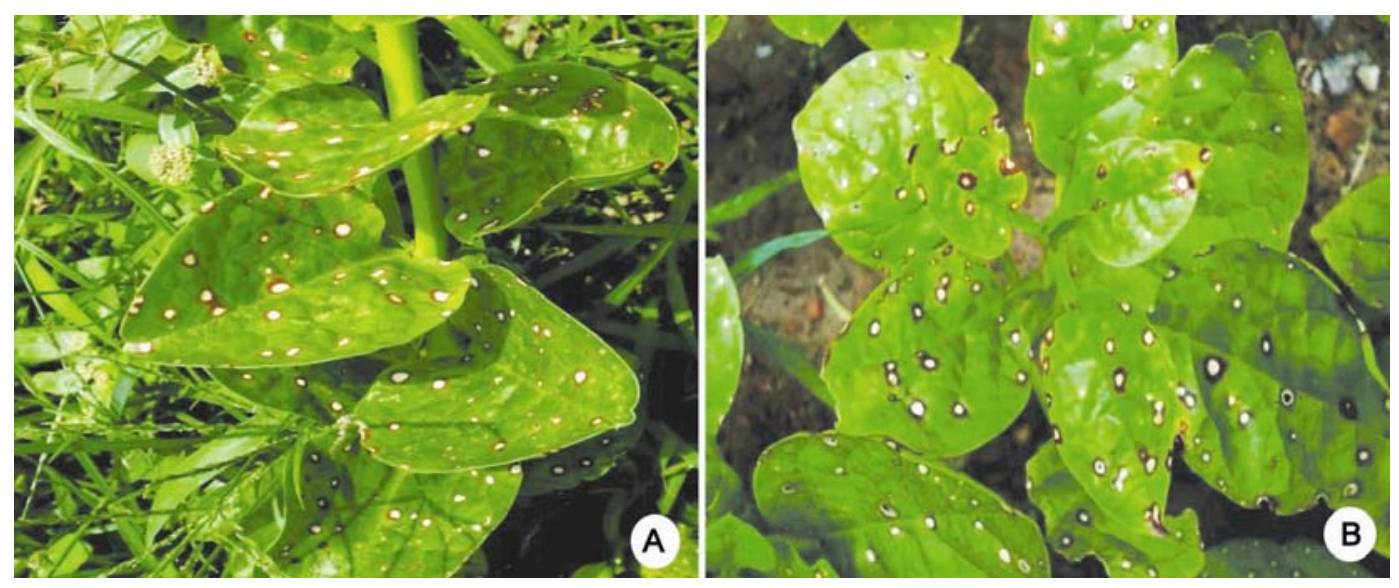

Fig.1. Infected leaves: A. Basella alba and B. Basella rubra.

Pathogenicity of the isolated fungi was tested following modified 'detached leaf technique' (Azad and Shamsi 2011). Instead of blotting paper moistened cotton bar was used to prepare moist chamber and autoclaved. Petri dishes containing water soaked cotton bar was used to maintain sufficient humidity to initiate infection. Healthy and young leaves of Basella spp. were collected. Leaves were washed with distilled water, surface sterilized with 10\% Clorox for five minutes and rinsed in sterilized water. Twenty five squire $\mathrm{mm}$ leaf pieces were placed in autoclaved Petri plates. Leaf pieces were inoculated with $5 \mathrm{~mm}$ (diameter) mycelial block that were previously cultured on PDA medium for seven days. All the fungi were tested to find out their pathogenic potentiality. Both ventral and dorsal sides of the leaves with and without pricking were inoculated with isolated fungi. Another set of leaf pieces inoculated with PDA block were maintained, which served as control. The plates were incubated at $25-28^{\circ} \mathrm{C}$. After three days of inoculation, examination of leaves under pathogenicity test was started and continued for 7 - 10 days for disease development. Lesion size and colour was recorded. 
Basella spp. are severely attacked by fungi throughout the world. Numerous small circular to sub-circular distinct leaf spots 2 - $4 \mathrm{~mm}$ in size were observed on upper surface of leaves. With development of fungi and progress of disease, off white lesions surrounded by purplish brown border. Corresponding ventral surface of leaves showed pale brown lesion. Sometimes several spots coalesce together to form large lesions (Fig. 1A, B).

A total of 12 species of fungi representing 8 genera of the class deuteromycetes were fA total of 12 species of fungi representing 8 genera of the class deuteromycetes were found to be associated with Basella alba and B. rubra. and to be associated with Basella alba and B. rubra. The isolated fungi were Alternaria alternata (Fr.) Keissler, Ascochyta sp., Aspergillus flavus Link., Aspergillus fumigatus Fresenius, Aspergillus niger van Tieghem, Aspergillus terreus Thom., Colletotrichum dematium (Pers. Ex Fr.) Grove, Curvularia pallescens Boedijn, Fusarium oxysporum Schlecht, Macrophomina phaseolina (Tassi) Goid and two species of Penicillium.

Prevalence of the fungi varied with species of Basella as well as healthy and diseased leaves. Pathogenicity test showed that Aspergillus fumigatus, A. terreus, F. oxysporum and C. pallescens were pathogenic to Basella spp.

Table 1. Frequency percentage of association of different fungi with healthy and anthracnose infected leaves of Basella alba and B. rubra.

\begin{tabular}{|c|c|c|c|c|}
\hline \multirow{3}{*}{ Name of fungi } & \multicolumn{4}{|c|}{ Hosts } \\
\hline & \multicolumn{2}{|c|}{ B. alba } & \multicolumn{2}{|c|}{ B. rubra } \\
\hline & Healthy & Diseased & Healthy & Diseased \\
\hline Alternaria alternata & 20.00 & 33.33 & - & 33.33 \\
\hline Ascochyta sp. & - & 9.50 & - & - \\
\hline Aspergillus fluvus & 17.00 & 33.33 & - & - \\
\hline A. fumigatus & 20.00 & 15.00 & - & 66.66 \\
\hline A. niger & 13.00 & 41.66 & 40.00 & 16.00 \\
\hline A. tereus & 33.33 & 40.00 & - & 33.33 \\
\hline Colletotrichum dematium & 4.00 & 5.11 & 33.33 & - \\
\hline C. palescense & 6.72 & 9.72 & - & - \\
\hline Fusarium oxysporum & 34.00 & 25.77 & - & 8.75 \\
\hline Macrophomina phaseolina & - & - & - & 8.75 \\
\hline Penicillium sp. 1 & 27.77 & 33.33 & 12.48 & 33.33 \\
\hline Penicillium sp. 2 & - & 10.00 & - & - \\
\hline
\end{tabular}

- = No isolate.

Altogether 9 species of fungi were isolated from healthy leaves of Basella alba. In order of their prevalence they were Fusarium oxysporum, A. terreus, Penicillium. sp.1, Alternaria alternata, Aspergillus fumigatus, A. flavus, A. niger, Curvularia pallescens and Colletotrichum dematium Their prevalence was 34.00, 33.33, 27.77, 20.00, 17.00, 13.00, 6.72 and 4.00\%, respectively.

Maximum of 11 species of fungi were isolated from infected leaves of B. alba. Prevalence of Aspergillus niger was the highest followed by A.terreus, A. alternata, A. flavus, Penicillium

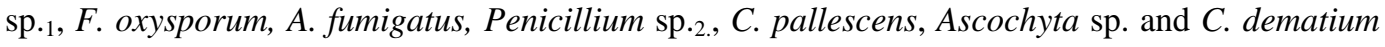


showing the prevalence of $41.00,40.00,33.33,25.77,15.00,10.00,9.75,9.50$ and $5.11 \%$, respectively.

Only 3 species of fungi, namely A. niger, C. dematium and Penicillium sp . $_{1}$, were associated with healthy leaves of Basella rubra showing the prevalence of $40.00,33.33$ and $12.48 \%$, respectively.

Seven species of fungi were associated with infected leaves of $B$. rubra .The isolated fungi were A. aternata, A. fumigates, A. niger, A. terreus, F. oxysporum, Macrophomina phaseolina and Penicillium sp.1, their prevalence was 33.33, 66.66, 16.66, 33.33, 8.75 and 33.33.\%, respectively (Table 1).

Pathogenecity test following detached leaf inoculation technique indicated that, Aspergillus fumigaus, A. terreus, F. oxyporum and C. pallescens produced symptoms on B. alba and B. rubra. Uninoculaed unpricked and pricked control did not produce any symptom. It was also recorded that in case of $B$. alba except $A$. fumigatus other test fungi were capable of causing infection on pricked dorsally and ventrally inoculated leaf pieces. But in B. rubra except $F$. oxyporum other test fungi were capable of causing infection on pricked dorsally and ventrally inoculated leaf pieces.

Leaf spot (Alternaria alternata (Fr.) Keissler), leaf and stem anthracnose (Colletotrichum capsici (Syd.) Butler \& Bisby), powdery mildew (Erysiphe cichoracearum DC.), Leaf and stem spot (Glomerella cigulata (Stonem.) Spauld. \& Schrenk.), Leaf rot (Pythium aphanidermatum (Eds.) Fitzp.) and wilt and rot (Sclarotium rolfsii Sacc.) of Basella spp. were reported in India by Mukerji and Bhasin (1986).

Pandey et al. (2011) reported brown leaf spot disease caused by Curvularia lunata (Wakker) Boedijn. Leaf spot cased by Pseudocercospora basellae was reported by Goh and Hsieh (1989). Damping-off on Basella rubra caused by Rhizoctonia solani Anastomosis Group 4 in Florida was reported by Fu and Zhang (2012).

Cercospora was reported on Basella sp. in Thailand by Anun et al. (2011). A fungus, Cercospora beticola, causes red spots and holes in leaves.

An undescribed disease was observed in Malabar nightshade (Basella rubra L.) in Miyagi Prefecture in 1996. Diseased plants showed large spots lesions with purple halos on leaves and stems. A pathogenic fungus was isolated from the diseased plants, and the leaf spot symptoms were observed in inoculated host plants. The fungus was identified as Fusarium proliferatum on the basis of morphological and cultural characteristics. This is the first report on the occurrence of the purple spot in Malabar nightshade in Japan (Hirei and Takayuki 2003).

In Bangladesh leaf spot is a destructive disease of Basella spp. caused by Cercosopra sp. Hossain (2007) reported about the disease and its control.

Present result is completely different from previous report by Fu and Zhang (2012), Anun et al. (2011) and Hirei and Takayuki (2003). This is the first record of association of Ascochyta sp., Aspergillus flavus, Aspergillus fumigatus, Aspergillus niger, Aspergillus terreus, 
Colletotrichum dematium, Curvularia pallescens, Fusarium oxysporum, Penicillium $\mathrm{sp}_{._{1}}$ and Penicillium sp.2 with Basella spp. Aspergillus fumigaues and A. terreus are mostly saprophytic in nature but produced symptom on inoculated leaves. Leaf spot of Basella caused by Curvularia pallescen and Fusarium oxysporum is new addition in the field of Mycology and plant Pathology.

\section{References}

Adhikari, R., N. Kumar, HN and Shruthi. 2012. A review on medicinal importance of Basella alba L. Int. J. Pharm. Sci. and Drug Res. 4(2): 110-114.

Anun, C., I. Hidayat and J. Meeboon. 2011. Genus Cercospora in Thailand: Taxonomy and Phylogeny (with a dichotomous key to species). Plant Pathology \& Quarantine 1(1): 11-87.

Azad, R. and S. Shamsi. 2011. Identification and pathogenic potentiality of fungi associated with Huttuyania cordata Thunb. Bangladesh J. Pl. Pathol. 20(2): 131-138.

Barnret, H. L. and S. B. Hunter. 1972. Illustrated genera of imperfect fungi. Burgess Publishing Company, U .S. A. 3rd Edition. pp. 44-45.

Booth, C. 1971. The Genus Fusarium. The Commonwealth Mycological Institute. England. 273 pp.

Ellis, M.B. 1971. Dematiaceous Hypomycetes. Commonwealth Mycological Institute, England. pp. 608.

Ellis, M.B. 1976. More Dematiaceous Hypomycetes. Common. Mycol. Instit., England. pp.507.

Ellis, M.B. and J.P. Ellis. 1997. Micro Fungi on Landplants. An Identification Handbook. Richmond Publishing Co. Ltd. pp. 868.

Fu, Y. and S. Zhang. 2012. Damping-off on Basella rubra caused by Rhizoctonia solani Anastomosis Group 4 in Florida. Horticultural Research 96(2): 288- 294.

Liao, X., China; Y. Fu, S. Zhang and Y.P. Duan. 2012. First report of damping-off on Basella rubra caused by Rhizoctonia solani Anastomosis. Group 4 in Florida 96(2): 288.2 - 288.2

Goh, T.K and W.H. Hsieh. 1989. Pseudocercospora basellae. Bot. Bull. Acad. Sin. 30:124-125.

Hirei, K. and A. Takayuki. 2003. Purple spot of Malabar nightshade (Basella rubra L.) caused by Fusarium proliferatum. Annual Report of the Society of Plant Protection of North Japan J. Code: F0809A. 54: 54-57.

Hossain, I. 2007. Research on crop disease management at Bangladesh Agriculture University. Advances in Plant pathology researches in Bangladesh. Plant Pathology Division, BARI. 251-282 pp.

Mukerji, K.G. and J. Bhasin. 1986. Plant diseases if India. A source Book. Tatta Mc.Grew-Hill Publishing Company Ltd., New Delhi. pp.467.

Pandey, R.K., P.K Gupta, M. Srivastava, S.R Singh and R. Gogoi. 2011. First report of brown leaf spot disease caused by Curvularia lunata infecting Indian spinach or poi (Basella rubra). Indian Phytopathology 64(2): 207.

Sutton, B.C. 1980. The Coelomycetes, Fungi Imperfecti with pycnidia Acervuli and stroma, Commonwealth Mycological Institute, Kew, Surrey, England. pp. 525-537.

Tuite, J. 1969. Plant Pathological methods. Fungi and Bacteria. Minneapolis, Minnesota. USA. Burgess Publishing Company. pp. 239. 